\title{
Traumatic pulmonary pseudocyst: A case report
}

\section{Travmatik pulmoner psödokist: Olgu sunumu}

İbrahim Koç, Ayşen Dökme

\begin{abstract}
Post-traumatic pulmonary pseudocyst (TPP) is an uncommon cavitary lesion of the lung. TPP is an air/fluid filled cavity without a true epithelial lining within the pulmonary parenchyma. TPPs usually occur following a motor vehicle accident or fall. Here we report a case of TPP which occurred after blunt chest trauma after a traffic accident. The chest X-ray few hours after the accident revealed mass/cyst like lesion on the right lover zone. Computed tomography of the thorax revealed bilateral cystic lesions on the parenchyma. The patient was treated conservatively with antibiotherapy. He was asymptomatic thereafter, and the traumatic pulmonary pseudocyst radiologically was completely resolved three months later. TPP might be confused with other cystic and cavitary lesions of the lung but radiological rapid onset is important in the differential diagnosis. J Clin Exp Invest 2014; 5 (2): 304-306
\end{abstract}

Key words: Lung injury, pseudocyst, tomography.

\section{INTRODUCTION}

Blunt chest trauma frequently leads to pulmonary contusions, hematomas or pleural effusions, but rarely leads to cyst formation [1]. Post-traumatic pulmonary pseudocyst (TPP) is an uncommon cavitary lesion of the lung. TPP is an air/fluid filled cavity without a true epithelial lining within the pulmonary parenchyma which usually happens after blunt chest traumas. TPP is seen most commonly in young adults and children [2]. Computed tomography of the thorax is an important step for early diagnosis. The injured area does not include epithelium or bronchial wall elements as it is in a true cyst, and it is not a result of an infectious process [1]. Traumatic pulmonary pseudocyst sometimes might be complicated with infection [3]. Clinical manifestations are hemoptysis, chest pain, cough, dyspnea, mild fever, and leukocytosis [4]. Spontaneous remission is the usual outcome; therapy is usually supportive unless

\section{ÖZET}

Post travmatik pulmoner psödokist (TPP) akciğerlerin nadir görülen kaviter hastalıklarından biridir. TPP akcğer parankiminde gerçek epitel bulundurmayan içi hava/sıvı ile dolu kaviter lezyonlardır. TPP genellikle motor kazaları veya düşme sonrası gelişir. Burada trafik kazası sonrası künt göğüs travması ile kliniğimize başvuran ve post travmatik pulmoner psödokist saptanan bir olgu sunulmaktadır. Travmadan birkaç saat sonra çekilen akciğer grafisinde sağ akciğer orta alt zonda kitle-kist benzeri lezyonlar olduğu görüldü. Akciğerin bilgisayarlı tomografisinde her iki akciğerde kistik lezyonlar olduğu görüldü. Hasta konservatif olarak antibiyotikle tedavi edildi. Takiplerinde hastanın şikâyetleri geriledi ve 3 ay sonra bakılan radyolojisinde lezyonlarda düzelme olduğu görüldü. TPP akciğerin diğer kaviter ve kistik lezyonlarıyla karışabilmekle beraber genellikle travmadan hemen sonra lezyonların radiyolojik olarak belirginleşmesi ayırıcı tanıda yol göstericidir.

Anahtar kelimeler: Akciğer hasarı, psödokist, tomografi

complications such as pneumothorax or infection of the cavitary lesion arise. In some cases even surgery is needed $[2,5]$. We here report a post-traumatic pulmonary pseudocyst, which is a rare case, happened after after a blunt chest trauma due to a traffic accident.

\section{CASE}

A 25 years old male was admitted to our hospital after a traffic accident. The patient had tibia fracture and was operated successfully. On the same day pos-operatively he began to suffer from dyspnea. He was a nonsmoker and had no previous medical history before the accident. On physical examination, he was hemodynamically stable and well perfused. Auscultation of the lungs revealed no pathologic sounds. His physical examination revealed normal body temperature $\left(36 \mathrm{C}^{\circ}\right)$, heart rate of 90 beats

Viranşehir Devlet Hastanesi, Göğüs Hastalıkları, Şanlıurfa, Türkiye

Correspondence: İbrahim Koç,

Viranşehir Devlet Hastanesi Göğüs Hastalıkları Bölümü, Şanlıurfa, Türkiye Email: ibrahimkoc1981@gmail.com

Received: 20.01.2014, Accepted: 01.02.2014

Copyright @ JCEI / Journal of Clinical and Experimental Investigations 2014, All rights reserved 
per minute, respiratory rate of 18 breaths per minute, blood pressure of $120 / 70 \mathrm{~mm} \mathrm{Hg}$, and SpO2 of $96 \%$ in room air. His initial blood analyses were as follows: WBC 15775/uL (80.7\% granulocytes, 8.5\% lymphocytes, $8.3 \%$ monocytes and the remaining other cell types); $\mathrm{Hb} 15 \mathrm{gr} / \mathrm{dL}$; Hct $43 \%$; platelets, $350,000 / \mathrm{uL}$, ESR $40 \mathrm{~mm} / 1 \mathrm{st}$ hour. His blood chemistry were as follows: glucose $85 \mathrm{mg} / \mathrm{dL}$, urea 120 $\mathrm{mg} / \mathrm{L}$, creatinine $2 \mathrm{mg} / \mathrm{L}$, protein $4.7 \mathrm{~g} / \mathrm{dL}$, albumin $3.6 \mathrm{~g} / \mathrm{dL}$. The chest X-rays revealed mass/cyst like lesion on the right lover zone (Figure 1). Computed tomography of the thorax revealed bilateral cystic lesions on the parenchyma.

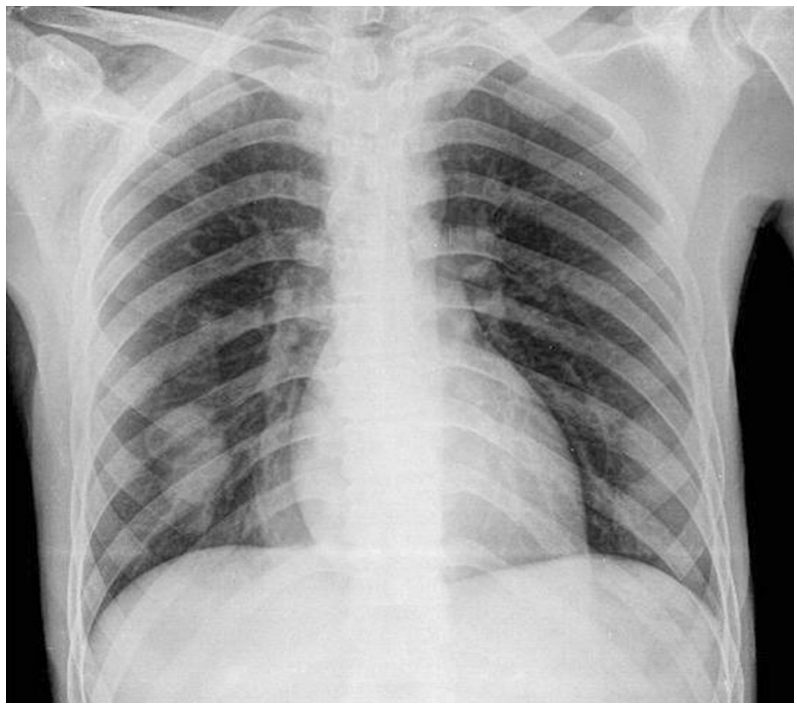

Figure 1. Posterio-anterior radiography of the lungs reveals mass/cyst like lesions on the right lover zone

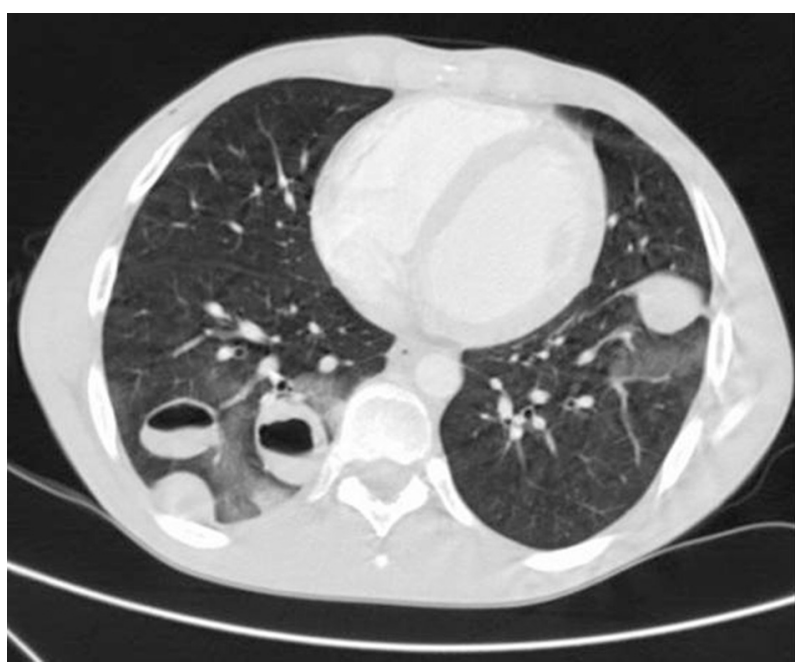

Figure 2. Computed tomography of the thorax revealed cystic lesions after the trauma

\section{DISCUSSION}

Post-traumatic pulmonary pseudocyst is an uncommon cavitary lesion of the lung. TPP is an air / fluid filled cavity without a true epithelial lining within the pulmonary parenchyma. Infections, congenital lesions, malignancies, and trauma can cause Cavitary lesions of the lung. TPPs are extremely rare manifestations of thoracic trauma, the incidence has been reported as $1-3 \%$ after blunt chest traumas in adults [6], and more common in younger people and children. TPPs usually occur following a motor vehicle accident or fall.

The pseudocyst develops via a mechanism that involves a sudden shearing force across the pulmonary parenchyma leading to an area of pulmonary contusion. One-way communication between the airway and the contused area leads to pneumatocele formation. People who are in young age have a more elastic chest wall, which permits greater transmission of kinetic energy to the lung parenchyma [7].Laseretion of the alveoli and the intertitium occurs after the rapid compression and decompression which results in cavities filled with air and/or fluid [7], which tend to grow until a pressure balance is achieved between the cavity and the surrounding tissue [6].

The traumatic lung pseudocyst may be evident in chest X-ray immediately after the trauma or within a few hours after the injury as was in our case. In some cases, the cyst might be full of blood thus it may not be visible until after a few days, when the bloody material is drained through the tracheobronchial tree [8]. In $50 \%$ of the cases, X-ray alone is helpful in the diagnosis [4]. Many mild cases of pseudocysts may go unnoticed if not checked with CT Which is more sensitive than a simple X-ray to detect such lesions.

Our case was a 25 years old male who had no previous medical history. Timing of the cysts made us put the TPP on the top of differential diagnosis. Same radiology cold happen in septic emboli but not in the same day radiology would be obvious.

Generally TPPs are self-limited, although the clinical course might be complicated by infection and bleeding [9]. However close follow up is recommended because of some rare but serious complications. These complications include pneumothorax, hemothorax, infection of pseudocyst - abscess formation and an increase in the size of the pseudocyst due to hemorrhage, which might need surgery [10]. 
Our patient was treated conservatively with antibiotherapy. He was asymptomatic thereafter, and the TPP was completely resolved three months later.

\section{REFERENCES}

1. Athanassiadi K, Gerazounis M, Kalantzi N, Kazakidis P, Fakou A, Kourousis D. Primary traumatic pulmonary pseudocysts: a rare entity. Eur J Cardiothorac Surg 2003;23:43-45.

2. Celik B, Basoglu A. Posttraumatic pulmonary pseudocyst: a rare complication of blunt chest trauma. Thorac Cardiovasc Surg 2006;54:433-435.

3. Santos GH, Mahendra T. Traumatic pulmonary pseudocysts. Ann Thorac Surg 1979;27:359-362.

4. Chon SH1, Lee CB, Kim H, Chung WS, Kim YH. Diagnosis and prognosis of traumatic pulmonary psuedo- cysts: a review of 12 cases. Eur J Cardiothorac Surg 2006;29:819-823.

5. Moore FA, Moore EE, Haenel JB, Waring BJ, Parsons PE. Post-traumatic pulmonary pseudocyst in the adult: pathophysiology, recognition, and selective management. J Trauma 1989;29:1380-1385.

6. Melloni G, Cremona G, Ciriaco P, et al., Diagnosis and treatment of traumatic pulmonary pseudocysts. J Trauma 2003;54:737-743.

7. Tsitouridis I. Traumatic pulmonary pseudocysts: CT findings. J Thorac Imaging 2007;22:247-251.

8. Fagan CJ, Swischuk LE. Traumatic lung and paramediastinal pneumatoceles. Radiology 1976;120:11-18.

9. De Dios JA, Paoletti L, Bandyopadhyay T. A 27-yearold man with pleuritic chest pain and hemoptysis after a rugby game. Chest 2009;136:1165-1167.

10. Shirakusa T. Traumatic lung pseudocyst. Thorax 1987;42:516-519. 